that industrialists are in some way more valuable than university teachers-that would be an impossible position to sustain-or that long university holidays and the freedoms of academic life should be paid for by smaller salaries, but that academic qualifications should not be regarded as the passport to a guaranteed income. University teachers, above all, should be aware of this. A degree is not a professional qualification. It does not entitle its holder to membership of a select association whose members are paid the same salary whatever job they do. It might, indeed, be better if there were much greater disparities between the salaries of graduates, particularly newly qualified ones. Not every intending academic can be turned into a systems analyst, but a more significant differential could help the process along.

It is also depressing that the association seems determined to establish standard rates of pay at all British universities. One of the striking developments in education in the United States has been the ability of lesser universities to pull themselves up by their own bootstraps by offering generous rates of pay. The University of Texas, supported by local business, is a good example of this. Are universities in Britain to be denied similar opportunities for self-improvemont?

The danger implicit in the association's argument is that, if university teachers are to be paid more, industrial salaries will also increase. And the hard-pressed schools, which can really make out a convincing case for a salary review, would be even less able to attract talented graduates. The next few years, which coincide with the graduation from universities of the children born in the "bulge" years, should offer the schools a real chance to recruit graduates. The universities, with the first major period of expansion after Robbins behind them, are likely to be absorbing fewer of their graduates than they have in the past few years. When all this is taken into account, can the association be said to have presented a convincing case ? On past form, Mr Aubrey Jones will be only too eager to decide.

\section{Engineering Compared}

THe case for the Common Market has seldom been put more cogently than in the recent OECD report on the enginecring industries of member countries (The Engineering Industries in North America-EuropeJapan, OECD, 1967, 30s.). The United States makes a smaller investment in its engineering industries than does Europe, but produces more than twice as much with almost half the number of employees. In spite of higher wage levels, the United States invested only $\$ 4,400$ million (at 1958 prices) in 1965 to achieve $\$ 162,000$ million worth of production. Europe, including the United Kingdom, invested $\$ 4,500$ million in the same year to achieve an output of $\$ 83,000$ million. Employment figures in 1965 were 6.7 million in the US and 12 million in Europe. During 1966 productivity in the US engineering industry was $\$ 25,000$ a head, three times the European average. By contrast, productivity was $\$ 10,000$ a head in France and Japan, $\$ 8,000$ in West Germany and $\$ 6,100$ in Britain.
The OECD report observes that these remarkable differences in efficiency are too important to be explained by a few causes. But it points out that disparities in the size and organization of the market, and hence in the scale and structure of production, are likely to be a dominant factor. The necessary reorganization of production in Europe, the report says, "can be fruitful only if accompanied . . . by effective measures to create a single European market, removing not only the traditional barriers (customs) but also all the other obstacles to trade (i.e. technical and administrative regulations, different legal and fiscal systems, currencies, etc.). In a word, the biggest and most acute problem facing the largest industrial sectors in Europe is the difficulty of surmounting those obstacles which prevent really economic production on a large scale."

The growth of British engineering industry compares unfavourably not only with that of the United States but also with its European competitors. As shown in the table below, its growth during the decade 1955-65 has been less than that of France or Germany and its relative share in the total production of OECD member countries has declined.

\begin{tabular}{|c|c|c|c|c|}
\hline \multirow{2}{*}{ Country } & $\begin{array}{l}\text { T OF ENGINEERIN } \\
\text { Per cent increase }\end{array}$ & \multicolumn{3}{|c|}{$\begin{array}{l}\text { INDUSTRIES } 1955-65 \\
\text { Per cent share of OECD }\end{array}$} \\
\hline & (1958 prices) & 1956 & 1960 & 1965 \\
\hline United Kingdom & 37 & $11 \cdot 6$ & $11 \cdot 2$ & $9 \cdot 4$ \\
\hline Germany & 91 & 8. & $10 \cdot 3$ & $9 \cdot 6$ \\
\hline France & 100 & $5 \cdot 1$ & $6 \cdot 0$ & $5 \cdot 9$ \\
\hline Italy & 91 & $2 \cdot 1$ & $2 \cdot 7$ & $2 \cdot 3$ \\
\hline United States & $\mathbf{5 7}$ & $61 \cdot 6$ & $54 \cdot 7$ & $54 \cdot 7$ \\
\hline Japan & 611 & $2 \cdot 2$ & $6 \cdot 1$ & $8 \cdot 6$ \\
\hline Europe OECD & 72 & $34 \cdot 0$ & $37 \cdot 4$ & $34 \cdot 5$ \\
\hline Total OECD & 73 & 100 & 100 & 100 \\
\hline
\end{tabular}

Diagnoses of what is wrong with British industry are two a penny and about as valuable to a patient who has heard it all before in one form or another. More to the point is what is right with American industry. The OECD report emphasizes the widely known fact that the structure of the United States domestic market favours very large-scale production with consequent maximum returns on capital. Greater profits lead to a higher degree of self-financing than in European companies; in absolute terms, investment is high and equipment is constantly renewed. A further difference is that, whereas in Europe new investment must usually be devoted to replacing capital stock or increasing production on the same technical base, the United States engineering industry can afford to divert the major part of new investment to the less immediately profitable ends of innovation and rationalization. Because plant is being used to its technical maximum, manpower is highly productive. The relatively small number of firms reduces administrative and technical personnel needs, which is a further factor in increasing productivity. Wages, and the standard of living, can be allowed to rise accordingly. All this has long been known in Europe but not, it seems, known well enough.

\section{Academic Issues}

THE National Board for Prices and Incomes is becoming a maid of all work for the British Government. The 
latest commission to land at the board's door is a survey of the pay of academic staff in universities. The government asked the board to take over this task, on a continuing basis, in November, and last week the board issued an invitation for written cvidence from interested organizations. The Association of University Teachers, quick off the mark, had submitted evidence before it was asked, and other more slowly moving organizations are certain to follow. The Department of Education and Science, the University Grants Committee and the Committee of Vice-Chancellors and Principals are all likely to respond to the eall, in their different ways. Some individuals may also feel impelled to write to the board, and their views, too, will be taken into account, although it would be a pity if the board were slowed down in its work by a mass of memoranda from individuals.

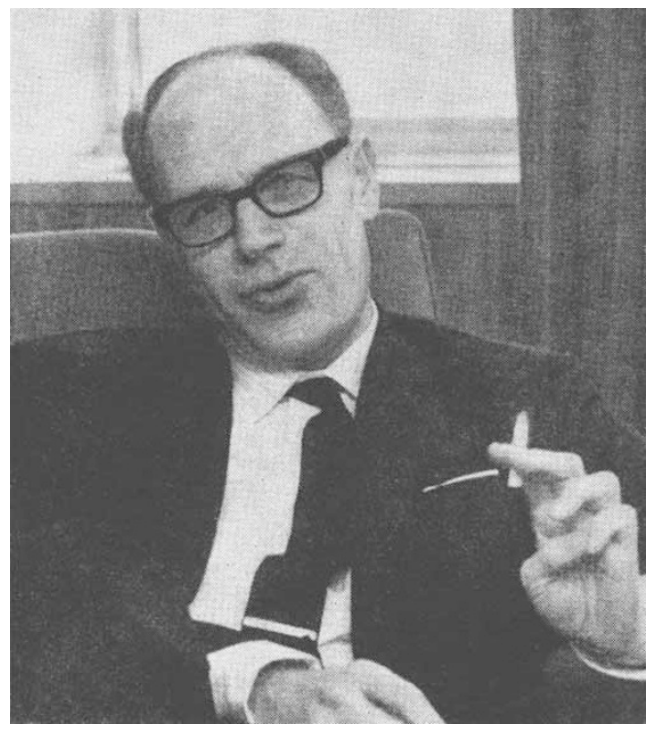

Mr Aubrey Jones; new look at university pay.

The last attempt to adjudicate on university salarics was made by the ill-fated National Incomes Commission in 1963. The commission, cosily called "Nicky" by its friends-and much worse things by the TUC, which refused to co-operate-folded up after the Conservative Government was defeated in the 1964 election. Since then, university pay has been settled by the Government, in collaboration with the University Grants Committee. But academics are always inclined to believe that the UGC is in cahoots with the Government, and the Association of University Teachers appealed for an independent review board. Offered the Prices and Incomes Board, it accepted, without, as it says, "prejudice to the future". The AUT argues that salaries of university teachers are much lower than those of people with equivalent qualifications in other walks of life; since the last review, it says, salaries of university teachers have increased by 5 per cent, while those outside academic life have had rises of up to 20 per cent. It rejects the selfless gestures of some professors who have said that in present economic circumstances university teachers should do without a rise. Professors, it implies, are the last people who should make these gestures, as they are well paid-the great mass of the 15,000 membership of the AUT is less well off. Professors would be the first to complain if the standard of academic work fell because universities could not recruit the best people, it suggests.

The board is not saying when it hopes to finish the survey. But it has a reputation for getting things done, and usually takes about 4-5 months, so there could be concrete results by the middle of this year. Mr Aubrey Jones, chairman of the board, has appointed himself chairman of the team which will investigatc university pay. He and another two members of the board team will be assisted by a staff working party consisting of at least another three people, who will be able to call on all the available expertisecconomists, statisticians, and the like-employed by the board. In addition, the committee can call on an enquiry team to go out and "ferret out the facts", so there seems no lack of professional zeal in the board's approach to the problem.

\section{Bigger Machine at Weston}

'IHe plan to build a new proton accelerator at Weston, Illinois, seems to be moving vigorously ahead. Among the several innovations which have been made since the decision was taken six months ago to go ahead with the machine is that the University of Toronto has joined the Universities Research Association Inc. This consortium of universities is formally responsible to the US Atomic Energy Commission for the construction and operation of the new accelerator. Forty-eight universities now belong to the consortium. The membership of the University of Toronto will no doubt excite the interest of other universities outside the United States.

The flavour of the Weston Project has changed significantly in the past few months, and particularly since the appointment last summer of Professor Robert Wilson as director of the project. For one thing, the accelerator is now known as the $200-400 \mathrm{GeV}$ machine, which amounts to an explicit recognition that at some stage in the development of the project the energy of the protons which the machine produces will be doubled to $400 \mathrm{GeV}$.

The possibility that accelerators might be graded is not of course new, but Professor Wilson seems to have hit on a particularly simple and economical way of doing this. To begin with, the machine at Weston will be fitted out with magnets designed to operate at a much higher field intensity than is necessary for the production of protons at $200 \mathrm{GeV}$. This means that when more money is available, it will be possible to increase the operating power of the magnets, chiefly by adding to the power supply. This is a simpler means of increasing the rating of a proton accelerator than some of the other devices which have been suggested-the addition of extra magnets, for example. All this amounts to a neat exploitation of the fact that in the larger accelerators, the costs of buying land and building a tunnel are a larger proportion of the total, which in turn implies that the costs of magnets are comparatively less important. Professor Wilson seems to have been able to push this balance even further by paying close attention to the design of cheap magnets-this is why it is possible for him to think of building into the new machine magnet capacity that will not be used for some time to come. 